\title{
THERMAL PREFERENCE INCREASES DURING LARVAL DEVELOPMENT OF PURE AND HYBRID ABALONE
}

\author{
KATHARINA ALTER, ${ }^{1,2 *}$ SARAH J. ANDREWARTHA, ${ }^{1,2}$ TIMOTHY D. CLARK ${ }^{1,2}$ \\ AND NICHOLAS G. ELLIOTT ${ }^{2}$ \\ ${ }^{1}$ Institute for Marine and Antarctic Studies, University of Tasmania, 20 Castray Esplanade, Battery \\ Point, Tasmania 7004, Australia; ${ }^{2}$ Agriculture and Food, Commonwealth Scientific and Industrial \\ Research Organization, Castray Esplanade, Battery Point, Tasmania 7004, Australia
}

\begin{abstract}
Temperature is one of the main factors influencing biological processes of ectothermic species. An optimum temperature of $16-18^{\circ} \mathrm{C}$ has been suggested for the development of early life stages of temperate Australian abalone, yet there are little physiological or behavioral data to support this suggestion. This study examines the acute thermal preferences $\left(T_{\text {pref }}\right)$, swimming speeds $(U)$, and oxygen consumption rates $\left(\mathrm{MO}_{2}\right)$ of veliger larvae of blacklip abalone [Haliotis rubra (Leach, 1814)], greenlip abalone [Haliotis laevigata (Donovan, 1808)], and their interspecies hybrid. Thermal preference and $U$ were measured in a thermal gradient with temperatures ranging from $12^{\circ} \mathrm{C}$ to $25^{\circ} \mathrm{C}$, and $\mathrm{MO}_{2}$ was measured at $4-7$ temperatures between $12^{\circ} \mathrm{C}$ and $32^{\circ} \mathrm{C}$. Thermal preference increased in all three groups of abalone during development from a $\mathrm{T}_{\text {pref }}$ of $16^{\circ} \mathrm{C}$ in 1 -day-old early veligers to a $\mathrm{T}_{\text {pref }}$ of $20^{\circ} \mathrm{C}$ in 3-day-old late veligers. Swimming speed increased with temperature in all three groups of abalone and increased with age in $H$. rubra and hybrids but not in $\mathrm{H}$. laevigata. Veliger $\mathrm{MO}_{2}$ increased throughout the ecologically relevant temperature range in all three abalone groups. Higher temperatures were examined in hybrids, and it was found that $\mathrm{MO}_{2}$ reached a peak at $25^{\circ} \mathrm{C}$ and declined thereafter. These results align with the temperatures that veligers may experience in their natural habitat and provide support that current temperatures maintained at Australian aquaculture hatcheries are within optimal ranges for larval performance.
\end{abstract}

KEY WORDS: behavioral thermoregulation, metabolism, early-life stages, abalone

\section{INTRODUCTION}

Temperature is a major abiotic factor influencing biological functions of ectotherms (Angilletta 2009). Through behavioral thermoregulation, ectothermic organisms can optimize performance traits to enhance survival and fitness. For example, temperatures can be selected to optimize digestive efficiency to enhance growth rates, or to optimize swimming speed to reduce the risk of predation (Videler 1993, Green \& Fisher 2004, Chapperon \& Seuront 2011a, 2011b). Studies of behavioral thermoregulation in marine gastropods have been conducted on adults (Casterlin \& Reynolds 1980, Hecht 1994, Muñoz et al. 2005); however, so far no study has examined the larval life stage. Assessing thermal preferences and tolerances of larvae can give insight into dispersal ranges and species distributions because they often reflect the thermal experiences encountered in the natural habitat (Hammond \& Hofmann 2010, Zippay \& Hofmann 2010).

Larvae of the blacklip abalone Haliotis rubra, greenlip abalone Haliotis laevigata, and their interspecies hybrid are potentially exposed to temperatures similar to those of adult individuals, because it has been suggested that larvae have a low dispersal range and develop in habitats where adults reside (Prince et al. 1987). Nevertheless, this idea remains speculative, with only a few larvae of $H$. rubra and no larvae of $H$. laevigata or their hybrid having been collected in the wild (Prince et al. 1987, Babcock \& Keesing 1999). Both pure species occur along the southern coast of Australia, including Tasmania. The interspecies hybrid is rare in nature, although adult hybrids have been found in areas where the two pure species live sympatrically (Brown 1995). Adults of H. rubra inhabit sheltered areas with

*Corresponding author. E-mail: katharina.alter@csiro.au DOI: $10.2983 / 035.036 .0114$ rocks and caves. Their distribution range extends further south than that of $H$. laevigata so that $H$. rubra experiences slightly colder temperatures throughout the year and is most commonly found at temperatures between $11^{\circ} \mathrm{C}$ and $19^{\circ} \mathrm{C}$. Adults of $H$. laevigata occur on rocks in open sandy areas, where the most common habitat temperatures range between $12^{\circ} \mathrm{C}$ and $23^{\circ} \mathrm{C}$ throughout the year (Shepherd 1973).

The hybrid is becoming a key commercial asset in Australian aquaculture because of its apparent growth advantage in the juvenile stage, yet the two pure species are also commercially cultured in Australia (Guo 2009). Current best industry practice recommends that embryos and larvae of Haliotis rubra should be reared at $16-18^{\circ} \mathrm{C}$ (Heasman \& Savva 2007). This temperature recommendation has also been adopted by aquaculture farmers for the rearing of Haliotis laevigata and hybrid larvae [L. McPherson, Jade Tiger Abalone (JTA), personal communication, November 2015]. Upper critical temperatures of the lecitotrophic larvae have not been reported but it has been shown that larval development slows at temperatures lower than $16^{\circ} \mathrm{C}$ and is arrested completely at $7.8^{\circ} \mathrm{C}$ in $H$. rubra and $7.2^{\circ} \mathrm{C}$ in $H$. laevigata (Grubert \& Ritar 2004). Although this general guideline for aquaculture (rearing at $16-18^{\circ} \mathrm{C}$ ) has been established based on growth and survival, little is known about the physiological and behavioral responses of Haliotis larvae to temperature. To address this knowledge gap, this study quantifies acute thermal preferences $\left(\mathrm{T}_{\text {pref }}\right)$, swimming speeds $(U)$, and oxygen consumption rates $\left(\dot{\mathrm{MO}}_{2}\right)$ of larval veliger H. rubra, H. laevigata, and their hybrid across an ecologically relevant temperature range. Moreover, given its significant commercial importance, the hybrid was challenged with higher temperatures to understand upper thermal tolerance limits. It was hypothesized that $\mathrm{T}_{\text {pref }}$ for larvae would be highest for $H$. laevigata and lowest for $H$. rubra based on the distribution of adult abalone and their natural habitat temperatures (Shepherd 1973). Further, it was predicted that upper 
thermal limits of hybrids would be marked by a decline in $\dot{\mathrm{MO}}_{2}$ once naturally occurring temperatures were exceeded.

\section{MATERIALS AND METHODS}

\section{Animal Rearing}

Larvae from Haliotis laevigata, Haliotis rubra, and their interspecies hybrid (H. rubra female crossed with $H$. laevigata male) were reared according to standard farm practices at the JTA hatchery in Indented Head, Australia. All experiments were conducted at the hatchery. Larvae were initially held in constantly flowing filtered sea water (filtered to 1 micron, $\mathrm{UV}$-treated), at $16.8^{\circ} \mathrm{C} \pm$ $0.1^{\circ} \mathrm{C}$ and $100 \%$ air saturation. Hybrid, H. laevigata and $H$. rubra larvae were obtained from three commercial spawning events in November 2015, December 2015, and March 2016. Due to varying fertilization success rates and the fact that larvae develop quickly and only spend $\sim 3$ days at $17^{\circ} \mathrm{C}$ in the target veliger form, multiple spawning events were required to obtain desired sample sizes.

Oxygen consumption rate $\left(\mathrm{MO}_{2}\right)$ of hybrids is dependent on developmental stage and it has been suggested that differences in $\dot{\mathrm{MO}_{2}}$ across the different stages (embryonic, trochophore larvae, veliger larvae, and settling larvae) are attributable to differences in activity level (Alter et al. 2016). Thus, only veliger larvae were chosen in the present study to target a developmental stage at which the mode of locomotion is stable. The $1^{\text {st }}, 2^{\text {nd }}$, and $3^{\text {rd }}$ day of the veliger larvae stage correspond to effective accumulative temperatures (EAT; in degree-hours) of $394-553^{\circ} \mathrm{C}-\mathrm{h}, 624$ $788^{\circ} \mathrm{C}$-h, and $842-1,008^{\circ} \mathrm{C}-\mathrm{h}$, respectively (Tables 1 and 2).

\section{Experimental Design}

Thermal Preference and Swimming Speed

Larval acute thermal preference $\left(\mathrm{T}_{\text {pref }}\right)$ (Reynolds \& Casterlin 1979) and thermal influence on swimming speed $(U)$ were measured in larvae from each of the three spawning events using a horizontal thermal gradient. This enabled the larvae to choose a temperature while removing the influence of gravity and the tendency of abalone larvae to crowd at the tank surface (Prince et al. 1987). The thermal gradient was custom built at the University of Tasmania and was similar to that described by Wiggins and Frappell (2000). The gradient consisted of a glass tube (54 cm length, $1 \mathrm{~cm}$ diameter, $42.42 \mathrm{ml}$ volume) that was embedded in an aluminum block and further insulated with foam to minimize heat exchange with the environment. Both ends of the aluminum block were connected to Peltier devices so that temperatures could be regulated using a custom-built electronic controller. Once the Peltier devices were turned on, a thermal gradient was established in less than $30 \mathrm{~min}$, similar to the thermal gradient used in Wiggins and Frappell (2000). The temperature gradient ranged from $12^{\circ} \mathrm{C}$ to $25^{\circ} \mathrm{C}$ and was skewed [temperature $\left({ }^{\circ} \mathrm{C}\right)=25.074-$ $0.040-0.004 \times$ position in gradient, $r^{2}=0.998$; Fig. 1]. Larval position within the gradient throughout the experimental period was observed through a thin viewing window in the aluminum block across the whole length of the glass tube. Three cameras (GoPro Hero 3) were installed above the viewing window and enabled the whole gradient to be captured. The cameras took photos at a rate of one per min throughout all experiments.

TABLE 1.

Experimental temperature (Temperature, $\left.{ }^{\circ} \mathrm{C}\right)$, developmental day and corresponding EAT $\left({ }^{\circ} \mathrm{C}-\mathrm{h}\right)$, number of individuals (ind/ml), number of replicates, and shell length [average size $(\mu \mathrm{m})$ mean $\pm \mathrm{SE}$, size range $(\mu \mathrm{m})]$ of Haliotis rubra, Haliotis laevigata, and hybrids from the December populations, and hybrids from the March population used for oxygen consumption measurements.

\begin{tabular}{|c|c|c|c|c|c|c|c|c|}
\hline \multirow[b]{2}{*}{ Population } & \multirow[b]{2}{*}{ Species } & \multirow[b]{2}{*}{ Temperature $\left({ }^{\circ} \mathrm{C}\right)$} & \multicolumn{2}{|c|}{ Development } & \multirow{2}{*}{$\frac{\text { Individuals }}{\text { (ind/ml) }}$} & \multirow[b]{2}{*}{ Replicates (n) } & \multicolumn{2}{|l|}{ Size } \\
\hline & & & Veliger day & EAT $\left({ }^{\circ} \mathbf{C}-h\right)$ & & & Mean $\pm \mathrm{SE}(\mu \mathrm{m})$ & Range $(\mu \mathrm{m})$ \\
\hline \multirow{18}{*}{ December 15} & H. rubra & 12 & 1 & 464 & $171-460$ & 7 & $294 \pm 3$ & $270-309$ \\
\hline & & 17 & 1 & 519 & $77-650$ & 7 & $291 \pm 3$ & $277-308$ \\
\hline & & & 2 & 655 & $293-554$ & 5 & $294 \pm 2$ & $282-301$ \\
\hline & & & 3 & 880 & $245-633$ & 5 & $290 \pm 2$ & $275-303$ \\
\hline & & 20 & 2 & 710 & $546-1,247$ & 6 & $289 \pm 3$ & $270-306$ \\
\hline & & 25 & 3 & 947 & $161-352$ & 7 & $286 \pm 3$ & 274-301 \\
\hline & H. laevigata & 12 & 1 & 494 & $137-495$ & 7 & $291 \pm 3$ & $271-311$ \\
\hline & & 17 & 1 & 553 & $77-357$ & 8 & & \\
\hline & & & 2 & 698 & $659-1,594$ & 6 & $287 \pm 6$ & $268-317$ \\
\hline & & & 3 & 937 & $386-899$ & 5 & & \\
\hline & & 20 & 2 & 757 & $597-1,159$ & 6 & & \\
\hline & & 25 & 3 & 1,008 & $470-1,006$ & 7 & $292 \pm 2$ & $282-307$ \\
\hline & Hybrid & 12 & 1 & 480 & $130-305$ & 6 & $295 \pm 4$ & $281-320$ \\
\hline & & 17 & 1 & 537 & $150-459$ & 6 & & \\
\hline & & & 2 & 678 & $288-882$ & 5 & $295 \pm 3$ & $275-305$ \\
\hline & & & 3 & 910 & 207-804 & 6 & & \\
\hline & & 20 & 2 & 734 & $199-654$ & 6 & & \\
\hline & & 25 & 3 & 979 & $313-625$ & 6 & $291 \pm 3$ & $273-307$ \\
\hline \multirow[t]{7}{*}{ March 16} & Hybrid & 12 & 3 & 965 & $190-603$ & 8 & $286 \pm 4$ & $254-303$ \\
\hline & & 17 & 1 & 544 & $193-484$ & 9 & & \\
\hline & & 20 & 2 & 698 & $224-790$ & 8 & & \\
\hline & & 25 & 1 & 480 & $65-514$ & 6 & $288 \pm 3$ & $263-300$ \\
\hline & & 28 & 3 & 929 & $56-321$ & 6 & & \\
\hline & & 30 & 2 & 743 & $118-394$ & 6 & $293 \pm 2$ & $280-308$ \\
\hline & & 32 & 2 & 788 & $122-318$ & 8 & & \\
\hline
\end{tabular}


TABLE 2.

Developmental day, corresponding EAT $\left({ }^{\circ} \mathrm{C}-\mathrm{h}\right)$, and number of individuals (ind/ml) of veliger larvae of Haliotis rubra, Haliotis laevigata, and hybrid abalone at the start of thermal preference measurements.

\begin{tabular}{|c|c|c|c|c|c|c|c|c|c|}
\hline \multirow[b]{2}{*}{ Species } & \multicolumn{3}{|c|}{ November 15} & \multicolumn{3}{|c|}{ December 15} & \multicolumn{3}{|c|}{ March 16} \\
\hline & Veliger day & EAT & Individuals & Veliger day & EAT & Individuals & Veliger day & EAT & Individuals \\
\hline \multirow[t]{5}{*}{ H. rubra } & 1 & 446 & 5 & 1 & 439 & 11 & & & \\
\hline & 2 & 628 & 6 & 1 & 493 & 11 & & & \\
\hline & 2 & 676 & 4 & 2 & 624 & 11 & & & \\
\hline & 3 & 842 & 13 & 2 & 681 & 29 & & & \\
\hline & 3 & 897 & 8 & 3 & 885 & 13 & & & \\
\hline \multirow{8}{*}{ H. laevigata } & & & & 1 & 394 & 25 & 1 & 483 & 4 \\
\hline & & & & 1 & 508 & 22 & 2 & 633 & 3 \\
\hline & & & & 2 & 687 & 20 & 2 & 670 & 3 \\
\hline & & & & 2 & 747 & 28 & 2 & 704 & 8 \\
\hline & & & & 3 & 921 & 22 & 3 & 880 & 7 \\
\hline & & & & 3 & 987 & 13 & 3 & 917 & 5 \\
\hline & & & & & & & 3 & 954 & 5 \\
\hline & & & & & & & 3 & 974 & 5 \\
\hline \multirow[t]{10}{*}{ Hybrid } & 1 & 431 & 2 & 1 & 472 & 21 & 1 & 449 & 17 \\
\hline & 2 & 663 & 7 & 2 & 687 & 16 & 1 & 466 & 8 \\
\hline & 2 & 722 & 6 & 3 & 873 & 20 & 1 & 482 & 6 \\
\hline & 3 & 901 & 5 & 3 & 936 & 16 & 1 & 503 & 6 \\
\hline & 3 & 951 & 11 & & & & 2 & 705 & 8 \\
\hline & & & & & & & 2 & 738 & 7 \\
\hline & & & & & & & 2 & 771 & 10 \\
\hline & & & & & & & 3 & 909 & 17 \\
\hline & & & & & & & 3 & 940 & 9 \\
\hline & & & & & & & 3 & 976 & 10 \\
\hline
\end{tabular}

Larvae of a single abalone group (Haliotis rubra, Haliotis laevigata, or their interspecies hybrid) were evenly dispersed throughout the glass tube using a syringe connected to $50 \mathrm{~cm}$ of aquarium tubing (see Table 2 for numbers of individuals $/ \mathrm{ml}$ ). Animals were left undisturbed for $1.5 \mathrm{~h}$ to distribute throughout the thermal gradient, after which 30-s videos were taken at four or five locations along the gradient (Celestron Deluxe Handheld Digital Microscope) to document the swimming speed of the animals. The temperature within the glass tube was subsequently measured every $2 \mathrm{~cm}$ using a thermocouple (a total of 25 readings) to quantify the thermal gradient after each experiment. In addition to the experimental trials, two control trials were conducted per day in which the temperature gradient was not established (i.e., Peltier devices turned off; uniform temperature of $19^{\circ} \mathrm{C}$, Fig. 1) to test whether the edges of the thermal gradient had any influence on larval distribution.

Thermal preference was determined for each trial by counting the number of larvae in each of the twenty-five 2-cm sections in the photos captured $1.5 \mathrm{~h}$ after the larvae were introduced into the thermal gradient. Numbers of larvae in consecutive sections were summed to determine the temperature range where $50 \%$ of the population occurred (Fig. 1). The average temperature of this range is considered herein to represent $T_{\text {pref }}$. Swimming speed $(\mathrm{mm} / \mathrm{s})$ was determined by manually tracking the distance traveled by larvae ( $n=6-10$ for each location) between every frame $(0.05 \mathrm{~s})$ in the 30-s videos using the plugin MTrackJ for Image J (FIJI) (Abramoff et al. 2004, Myrick 2009, Schindelin et al. 2015).

\section{Oxygen Consumption Rate}

Oxygen consumption rate $\left(\mathrm{MO}_{2}\right)$ was measured on 3 days in December 2015 with veliger larvae of Haliotis rubra, Haliotis laevigata, and their interspecies hybrid, and on 3 days in March 2016 with hybrids only. Methods for measuring $\mathbf{M O}_{2}$ are described by Alter et al. 2016. In brief, respiration chambers consisted of 24 wells (each $2.7 \mathrm{ml}$ ) within a galvanized aluminum plate. The aluminum plate was placed on a sensor dish reader (PreSens, Germany) which measured the oxygen content within each chamber at a rate of four readings per minute. The measuring unit (aluminum plate and sensor dish reader) was placed in a temperature-controlled room to manipulate temperature between temperature treatments and to ensure stable temperature during each experimental run. Individual respiration chambers were sealed with acrylic lids that contained a capillary hole and tube to prevent pressurizing the chamber during closure. Preliminary experiments showed that oxygen exchange through the capillary system was negligible. Veliger larvae swim constantly and stir the water such that a mechanical stirring mechanism was unnecessary. For each trial, batches of larvae from a single species group were transferred to respiration chambers filled with fresh seawater enriched with oxygen to a maximum of $120 \%$ air saturation $\left(\mathrm{O}_{2}\right.$ sat $)$ to ensure normoxic conditions once measurements commenced. The measurements commenced immediately after the chambers were hermetically sealed. The number of individuals per chamber varied between 56 and $1594 \mathrm{ind} / \mathrm{ml}$ (Table 1). A previous study has shown that different densities throughout this range do not influence larval abalone $\dot{M O}_{2}$ when calculated per individual (Alter et al. 2016). Percentage air saturation was measured until oxygen dropped below $70 \% \mathrm{O}_{2}$ sat (typically $\sim 2 \mathrm{~h}$ at $32^{\circ} \mathrm{C}$ and $\sim 5 \mathrm{~h}$ at $12^{\circ} \mathrm{C}$ ). Sensors were calibrated in air-saturated seawater for $100 \%$ $\mathrm{O}_{2}$ sat and in sodium sulfite-saturated seawater for $0 \% \mathrm{O}_{2}$ sat. Four chambers without individuals served as blanks to 


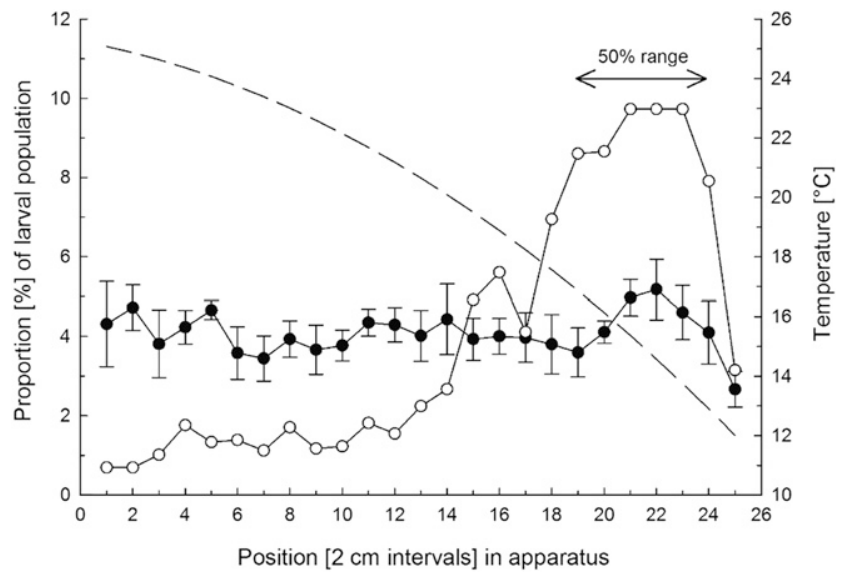

Figure 1. Example of the distribution (percent of population per $\mathbf{2} \mathrm{cm}$ ) of one abalone larvae population (open circles, example of Haliotis rubra, $493^{\circ} \mathrm{C}-\mathrm{h}$ ) in the thermal gradient apparatus in the presence of a thermal gradient (dashed line). Black circles represent the average distribution during control runs (mean $\pm \mathrm{SE}, n=5$ ) in the absence of a thermal gradient (uniform temperature of $19^{\circ} \mathrm{C}$, Peltier devices turned off). The horizontal arrow indicates $50 \%$ of larval population for which the average temperature was used as $\mathbf{T}_{\text {pref }}$ value.

account for microbial respiration at each temperature. Blanks and $\mathrm{MO}_{2}$ (in $\mathrm{pmol} / \mathrm{h} /$ ind) were calculated from the linear decrease in oxygen measured in each respiration chamber according to Eq. 1:

$$
\dot{\mathrm{M}} O_{2}=\frac{\Delta F O_{2}}{\Delta t} \times\left(P_{B}-P_{S}\right) \times \beta_{O_{2}} \times \mathrm{Vol} \times 0.2093
$$

Where $\Delta F O_{2}$ is the change in fractional oxygen concentration over time, $t$ is time (s), $P_{\mathrm{B}}$ is the barometric pressure $(\mathrm{kPa}), P_{\mathrm{S}}$ is the saturation vapor pressure of water $(\mathrm{kPa}), \beta_{\mathrm{O} 2}$ is the capacitance of water for oxygen, $\mathrm{Vol}$ is the chamber volume minus the larvae volume (l, assuming $1 \mathrm{~g}$ wet mass equals $1 \mathrm{ml}$ and 1 larvae equals $1.4 \mu \mathrm{g}$ ), and 0.2093 is the fractional concentration of oxygen in water.

Abalone larvae are only spawned commercially twice per year in Australia, and the larvae develop very quickly with the veliger life stage only lasting 3 days at the commercial rearing temperature of $16-18^{\circ} \mathrm{C}$. As a result, $\mathrm{MO}_{2}$ experiments were conducted during December and March to gain a sufficient sample size. To determine the effect of temperature on $\mathbf{M O}_{2}$ of Haliotis rubra, Haliotis laevigata, and hybrid larvae, experiments were conducted at $12^{\circ} \mathrm{C}, 17^{\circ} \mathrm{C}, 20^{\circ} \mathrm{C}$, and $25^{\circ} \mathrm{C}$ in December. Further, to determine the temperature where $\mathrm{MO}_{2}$ becomes compromised in the most important commercial abalone, that is, hybrid larvae, $\dot{\mathrm{MO}} 2$ of hybrids was determined at the aforementioned temperatures plus the additional temperatures of $28^{\circ} \mathrm{C}, 30^{\circ} \mathrm{C}$, and $32^{\circ} \mathrm{C}$ in March 2016. The $\dot{\mathrm{MO}} 2$ data were collected over 3 days because it was logistically impractical to measure $\dot{M O}_{2}$ at all temperatures within 1 day. It was not expected that larval $\mathrm{MO}_{2}$ would vary across this time because hybrid larvae maintain constant $\dot{\mathrm{MO}}{ }_{2}$ during their 3 days as veligers at a constant temperature of $16^{\circ} \mathrm{C}$ (Alter et al. 2016). However, two experimental considerations further minimized the potential effect of experimental day on $\mathrm{MO}_{2}$. First, during the December experiment, the $\mathrm{MO}_{2}$ of larval H. rubra,
$H$. laevigata, and hybrids was measured at $17^{\circ} \mathrm{C}$ on each of the three consecutive days to determine if $\mathrm{MO}_{2}$ at a stable temperature changed throughout the three experimental days. Second, the order at which $\mathrm{MO}_{2}$ was determined at temperatures other than $17^{\circ} \mathrm{C}$ was randomized between December and March experiments. In December, larval $\mathrm{MO}_{2}$ was measured at $12^{\circ} \mathrm{C}$, $20^{\circ} \mathrm{C}$, and $25^{\circ} \mathrm{C}$ at the $1^{\text {st }}, 2^{\text {nd }}$, and $3^{\text {rd }}$ day of veliger larvae development, respectively ( $n=5-8$ replicates for each abalone group and temperature, Table 1). In March, $\dot{\mathrm{MO}} 2$ of hybrids was measured at $25^{\circ} \mathrm{C}, 20^{\circ} \mathrm{C}$, and $12^{\circ} \mathrm{C}$ at the $1^{\text {st }}, 2^{\text {nd }}$, and $3^{\text {rd }}$ day, respectively ( $n=5-9$ replicates for each temperature, Table 1). The additional temperature treatments to determine the temperature where hybrid $\dot{\mathrm{MO}}_{2}$ becomes compromised were conducted in March 2016 as follows: $17^{\circ} \mathrm{C}$ on the $1^{\text {st }}$ day, $30^{\circ} \mathrm{C}$ and $32^{\circ} \mathrm{C}$ on the $2^{\text {nd }}$ day, and $28^{\circ} \mathrm{C}$ on the $3^{\text {rd }}$ day (Table 1 ). After each trial, larvae were preserved in $10 \%$ formalin and transported to CSIRO, Hobart, Australia, where they were counted and veliger shell lengths were measured (Table 1).

\section{Statistical Analyses}

Statistical analyses were conducted using SigmaPlot 13.0. Shapiro-Wilk tests were used to test for normality and BrownForsythe tests were used to test for equal variances. Multiple pairwise comparisons were conducted with Student-NewmanKeuls tests. Significance was considered at $P<0.05$.

Differences between the distributions of the larvae with and without a thermal gradient were tested using Chi-square tests. Then, differences in $\mathrm{T}_{\text {pref }}$ between species and developmental days were examined using two-way analysis of variance (ANOVA).

Measures of $U$ data were pooled at each developmental day for each group of abalone. Then, the influence of temperature, developmental days, and group of abalone on $U$ was tested using a three-way ANOVA.

The $\mathrm{MO}_{2}$ data of hybrids from the March population were log-transformed to satisfy requirements for normality and a one-way ANOVA was conducted to determine the temperature at which $\mathrm{MO}_{2}$ became compromised and started to decline. For $\mathrm{MO}_{2}$ data at $17^{\circ} \mathrm{C}$ for each group of abalone from the December population, a one-way ANOVA was conducted to test if $\mathrm{MO}_{2}$ changed during development. Oxygen consumption rate did not change during development at $17^{\circ} \mathrm{C}$ and data were pooled afterward for each group of abalone. $\mathrm{MO}_{2}$ data at $12-$ $25^{\circ} \mathrm{C}$ for the December and March populations were used to test for differences between temperatures and groups of abalone. For these data, normality was not satisfied and a nonparametric Scheirer-Ray Hare test was conducted (Scheirer et al. 1976, Sokal \& Rohlf 1995).

\section{RESULTS}

\section{Thermal Preference}

Veliger distributions were significantly different with and without the thermal gradient (Chi-square test, $P<001$; Fig. 1). The $T_{\text {pref }}$ was similar between groups of abalone and increased significantly during development from 1- to 3-day-old veligers (two-way ANOVA, group of abalone $F_{2,34}=1.26, P>0.05$; development $F_{2,34}=21.14, P<0.001$; Fig. 2). Values of $\mathrm{T}_{\text {pref }}$ increased from $15.9^{\circ} \mathrm{C} \pm 1.0^{\circ} \mathrm{C}$ to $19.5^{\circ} \mathrm{C} \pm 0.1^{\circ} \mathrm{C}$ in Haliotis rubra $(P<0.01)$, from $17.0^{\circ} \mathrm{C} \pm 0.3^{\circ} \mathrm{C}$ to $20.0^{\circ} \mathrm{C} \pm 0.6^{\circ} \mathrm{C}$ in 


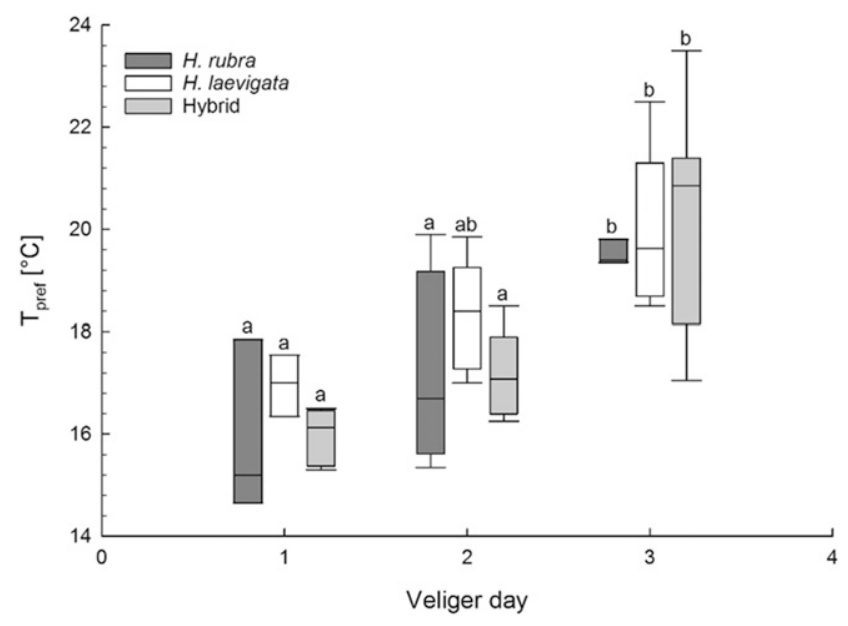

Figure 2. Thermal preference $\left(\mathrm{T}_{\text {pref }},{ }^{\circ} \mathrm{C}\right)$ of Haliotis rubra (dark gray bars), Haliotis laevigata (open bars), and hybrid larvae (light gray bars) during veliger development (days). The box shows the $95 \%$ range and is offset for visual clarity. The horizontal line indicates the median. Whiskers represent the lowest and highest values. Sample sizes are in Table 1. Different lowercase letters indicate significant differences between veliger days within each abalone group (two-way ANOVA, Student-NewmanKeuls test, $P<0.05$ ).

Haliotis laevigata $(P<0.02)$ and from $16.0^{\circ} \mathrm{C} \pm 0.2^{\circ} \mathrm{C}$ to $20.2^{\circ} \mathrm{C} \pm$ $0.8^{\circ} \mathrm{C}$ in hybrids $(P<0.01$; Fig. 2$)$.

\section{Swimming Speed}

The swimming speed $(U, \mathrm{~mm} / \mathrm{s})$ of veligers was significantly influenced by the abalone group (Haliotis rubra, Haliotis laevigata, or hybrid), temperature, and developmental day (three-way ANOVA, group of abalone $F_{2,593}=14.96, P<$ 0.001 ; temperature $F_{3,593}=261.25, P<0.001$; day $F_{2,593}=$ 13.00, $P<0.001$; Fig. 3). There were significant interactions between temperature and group of abalone, between temperature and developmental day and between group of abalone, temperature, and developmental day (three-way ANOVA, temperature/group of abalone $F_{6,593}=7.01, P<0.001$; temperature/day $F_{6,593}=3.69, P=0.001$; group of abalone/temperature/day $\left.F_{12,593}=2.37, P=0.006\right)$. For $H$. laevigata veliger larvae, $U$ at $12^{\circ} \mathrm{C}(1.96 \pm 0.14 \mathrm{~mm} / \mathrm{s}), 17^{\circ} \mathrm{C}(2.18 \pm 0.12 \mathrm{~mm} / \mathrm{s})$, $20^{\circ} \mathrm{C}(2.75 \pm 0.13 \mathrm{~mm} / \mathrm{s})$, and $25^{\circ} \mathrm{C}(3.97 \pm 0.14 \mathrm{~mm} / \mathrm{s})$ was similar across developmental days $(P>0.05)$, with values significantly higher at $25^{\circ} \mathrm{C}(P<0.001$; Fig. 3B). For H. rubra, $U$ at $12^{\circ} \mathrm{C}, 17^{\circ} \mathrm{C}$, and $20^{\circ} \mathrm{C}$ was similar between developmental days $(P>0.05)$ and averaged $1.99 \pm 0.14,2.38 \pm 0.10$, and $2.91 \pm$ $0.10 \mathrm{~mm} / \mathrm{s}$, respectively. At $25^{\circ} \mathrm{C}, U$ of $H$. rubra increased during veliger development and was lowest in 1-day-old veligers (4.10 $\pm 0.17 \mathrm{~mm} / \mathrm{s})$, significantly higher in 2-day-old veligers $(5.06 \pm$ $0.17 \mathrm{~mm} / \mathrm{s}, P<0.005)$ and highest in 3-day-old veligers $(5.93 \pm$ $0.19 \mathrm{~mm} / \mathrm{s}, P<0.001)$. Similar to H. laevigata, $U$ of $H$. rubra was not significantly different between $12^{\circ} \mathrm{C}$ and $17^{\circ} \mathrm{C}(P>$ $0.05)$ but was significantly elevated at $25^{\circ} \mathrm{C}(P<0.001)$ at all tested veliger days (Fig. 3A). For hybrid larvae, $U$ at $12-20^{\circ} \mathrm{C}$ was similar between developmental days $(P>0.05)$ and increased significantly between each temperature $(P<0.03)$ from $1.66 \pm 0.10 \mathrm{~mm} / \mathrm{s}$ at $12^{\circ} \mathrm{C}$ to $2.38 \pm 0.14 \mathrm{~mm} / \mathrm{s}$ at $17^{\circ} \mathrm{C}$ and $3.38 \pm$ $0.14 \mathrm{~mm} / \mathrm{s}$ at $20^{\circ} \mathrm{C}$. At $25^{\circ} \mathrm{C}, U$ of hybrids increased across development like those of $H$. rubra, and was significantly lower in 1-day-old veligers $(4.19 \pm 0.15 \mathrm{~mm} / \mathrm{s})$ in comparison with 3day-old veligers $(6.09 \pm 0.21 \mathrm{~mm} / \mathrm{s})(P<0.001$; Fig. 3C).

\section{Oxygen Consumption Rate}

The $\mathrm{MO}_{2}$ (pmol $\mathrm{O}_{2} / \mathrm{h} / \mathrm{ind}$ ) of Haliotis rubra, Haliotis laevigata, and hybrids measured in December at $17^{\circ} \mathrm{C}$ was stable over the 3-day developmental period (one-way ANOVA, $H$. rubra $F_{2,14}=0.23, P>0.05 ; H$. laevigata $F_{2,16}=1.06, P>0.05$; hybrids $F_{2,14}=0.56, P>0.05$; Fig. 4). For the December populations, $\mathrm{MO}_{2}$ was influenced by temperature and group of abalone (two-way ANOVA, temperature $H_{3,126}=86.91, P<$ 0.001 ; group of abalone $H_{3,126}=16.09, P<0.001$; Fig. 5). For both $H$. rubra and hybrids, the $\dot{M O}_{2}$ from the December population increased gradually with increasing temperature from $12^{\circ} \mathrm{C}$ to $25^{\circ} \mathrm{C}(P>0.05)$, whereas $\mathrm{MO}_{2}$ of $\mathrm{H}$. laevigata was similar between $17^{\circ} \mathrm{C}$ and $20^{\circ} \mathrm{C}(P>0.05)$ and between $20^{\circ} \mathrm{C}$ and $25^{\circ} \mathrm{C}\left(P>0.05\right.$; Fig. 5). At $12^{\circ} \mathrm{C}, 17^{\circ} \mathrm{C}$, and $20^{\circ} \mathrm{C}$, all abalone had a similar $\dot{\mathrm{MO}}_{2}$ with average values of $73.65 \pm 1.50$, $93.08 \pm 1.81$, and $114.85 \pm 3.83 \mathrm{pmol} \mathrm{O}_{2} / \mathrm{h} / \mathrm{ind}$, respectively $(P>$ $0.05)$. At $25^{\circ} \mathrm{C}, \dot{\mathrm{MO}_{2}}$ of $H$. laevigata $\left(118.31 \pm 4.55 \mathrm{pmol} \mathrm{O}_{2} / \mathrm{h} /\right.$ ind) was significantly lower than that of $H$. rubra (151.21 \pm 9.61 pmol $\left.\mathrm{O}_{2} / \mathrm{h} / \mathrm{ind}\right)$ and hybrids $(147.53 \pm 7.71 \mathrm{pmol} \mathrm{O} / \mathrm{h} / \mathrm{ind}, P<$ 0.05; Fig. 5).

For the March spawning, hybrid $\mathrm{MO}_{2}$ increased gradually from $12^{\circ} \mathrm{C}\left(74.42 \pm 2.20 \mathrm{pmol} \mathrm{O}_{2} / \mathrm{h} /\right.$ ind $)$ to a maximum value at $25^{\circ} \mathrm{C}\left(176.73 \pm 6.19 \mathrm{pmol} \mathrm{O}_{2} / \mathrm{h} / \mathrm{ind}, P<0.001\right)$, after which it decreased until $28^{\circ} \mathrm{C}\left(147.79 \pm 9.78 \mathrm{pmol} \mathrm{O}_{2} / \mathrm{h} / \mathrm{ind}, P=0.017\right)$. Oxygen consumption rates $\left(\mathrm{MO}_{2}\right)$ remained stable from $28^{\circ} \mathrm{C}$ to $32^{\circ} \mathrm{C}$ (average value $=133.86 \pm 4.43 \mathrm{pmol} \mathrm{O}_{2} / \mathrm{h} / \mathrm{ind}, P>0.05$ ) (one-way ANOVA, temperature $F_{6,44}=31.19, P<0.001$; Fig. 6). In comparison with larvae of Haliotis rubra, Haliotis laevigata, and hybrids from the December population, larvae of hybrids from the March population had a similar $\mathrm{MO}_{2}$ at $12^{\circ} \mathrm{C}(P>0.05)$ but $20 \%$ increased values at $17^{\circ} \mathrm{C}$ and $20^{\circ} \mathrm{C}$. At $25^{\circ} \mathrm{C}$, hybrid larvae from March had $15 \%$ higher $\dot{\mathrm{MO}}_{2}$ values in comparison with $H$. rubra and hybrid larvae from December and $30 \%$ higher values in comparison with $H$. laevigata larvae from December $(P<0.05)$ (two-way ANOVA, temperature $H_{3,126}=86.91, P<0.001$; group of abalone $H_{3,126}=16.09, P<$ 0.001 ; Figs. 5 and 6).

\section{DISCUSSION}

Thermal preference $\left(\mathrm{T}_{\text {pref }}\right)$ of Haliotis rubra, Haliotis laevigata, and hybrid larvae ranged from $16^{\circ} \mathrm{C}$ in early veligers to $20^{\circ} \mathrm{C}$ in late veligers (Fig. 2). Ecological conclusions are difficult to draw because few larvae have been found in the wild (Breen \& Adkins 1980, McShane et al. 1988, Babcock \& Keesing 1999). Larvae in this study are from third generationselected broodstock, with founder populations originating mainly from Victorian coastal and bay populations of abalone. In this region, minimum and maximum sea temperatures are $11.8^{\circ} \mathrm{C}$ and $25.4^{\circ} \mathrm{C}$, respectively, with an annual mean of $18.6^{\circ} \mathrm{C}$ (Australian Government Bureau of Meteorology 2016). The $T_{\text {pref }}$ of larvae determined in this study and $T_{\text {pref }}$ measured in adult $\mathrm{H}$. rubra and $\mathrm{H}$. laevigata of $17^{\circ} \mathrm{C}$ and $19^{\circ} \mathrm{C}$, respectively, fit within the natural temperature range of the founders (Gilroy \& Edwards 1998).

All three abalone groups in this study increased $\mathrm{T}_{\text {pref }}$ during larval development (Fig. 2). Abalone veligers close to settlement might select warmer waters to decrease the time needed to 

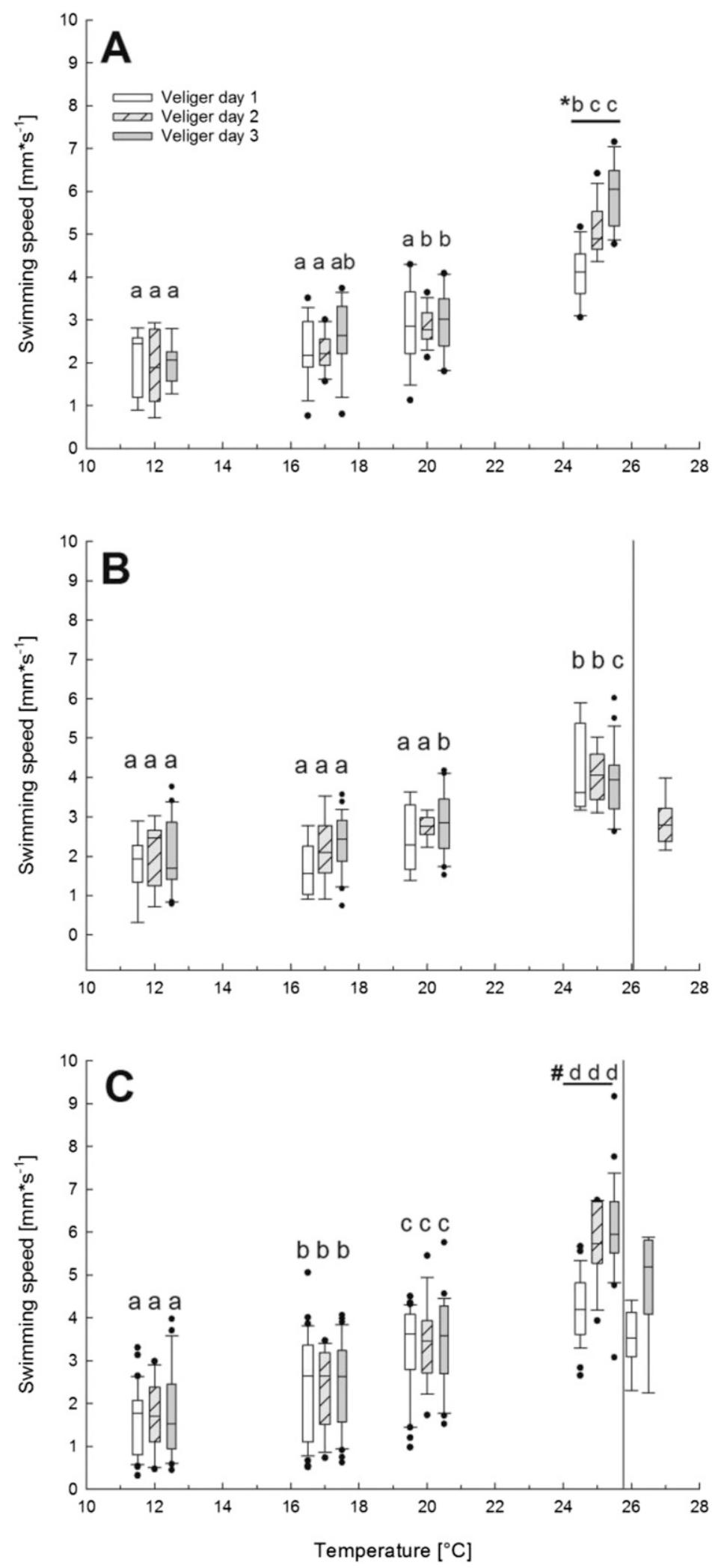

Figure 3. Swimming speed $(U, \mathrm{~mm} / \mathrm{s})$ of (A) Haliotis rubra, (B) Haliotis laevigata, and (C) hybrid larvae at veliger day 1 (white), day 2 (striped), and day 3 (gray) measured at $12^{\circ} \mathrm{C}, 17^{\circ} \mathrm{C}, 20^{\circ} \mathrm{C}$, and $25^{\circ} \mathrm{C}$, respectively (groups offset on the temperature axis for visual clarity). The meaning of boxes and whiskers are as described in Fig. 2. Dots symbolize outliers. $n=7-37$. Different lowercase letters indicate significant differences between temperature treatments for a given veliger day. \# Indicates significant differences between veliger day 1 and 3 at a given temperature. * indicates significant differences between all veliger days at a given temperature. $U$ above $25^{\circ} \mathrm{C}$, shown to the right of the vertical line, was not collected for all abalone types and was therefore not included in the statistical analysis (three-way ANOVA, Student-Newman-Keuls test, $P<0.05$ ). 


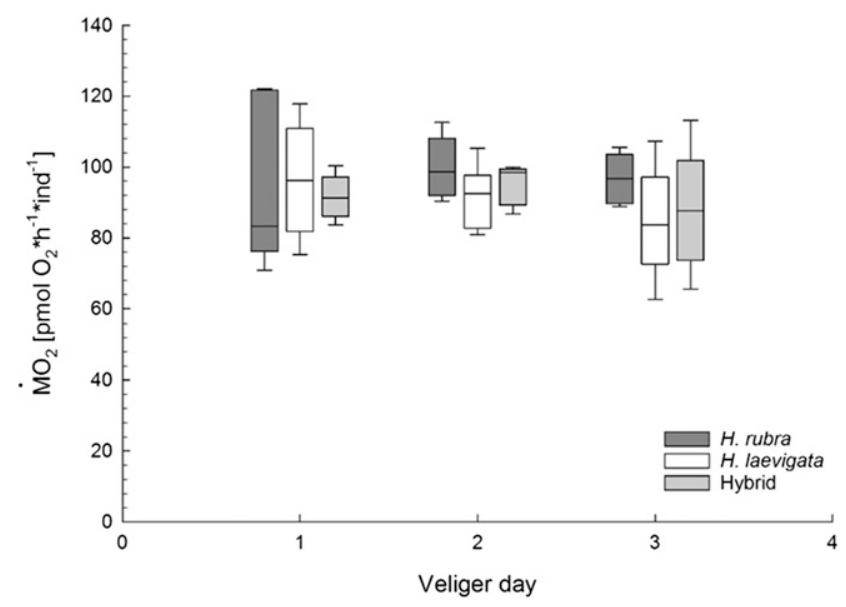

Figure 4. Oxygen consumption rate $\left(\mathrm{M}_{2}, \mathrm{pmol} \mathrm{O}_{2} / \mathrm{h} / \mathrm{ind}\right)$ of Haliotis rubra (dark gray bars), Haliotis laevigata (open bars), and their interspecies hybrid (light gray bars) during veliger larvae development (days) at $17^{\circ} \mathrm{C}$. The meaning of boxes and whiskers are as described in Fig. 2. $n=5-8$.

metamorphose, subsequently increasing their chance of survival and successful settlement. Developmental time is strongly dependent on temperature and individuals will pass the vulnerable metamorphosis stage more rapidly by selecting higher temperatures at the end of the larval phase (Leighton 1972). Larval amphibians also increase $\mathrm{T}_{\text {pref }}$ during development and select warmer waters at the settlement stage to facilitate faster metamorphosis and reduce predation (Floyd 1984, Dupré \& Petranka 1985, Wollmuth et al. 1987). Similar to amphibians, metamorphosing abalone larvae are likely to be more susceptible to predation because they have lower mobility in comparison with swimming larvae and are less protected than juveniles and adults which have protective juvenile/adult shells (Crofts 1937).

Ectotherms often select temperatures below their maximal physiological capacity (Martin \& Huey 2008). Although a maximum level was not determined for Haliotis rubra and Haliotis laevigata, the decline in hybrid $\mathrm{MO}_{2}$ at temperatures higher than $25^{\circ} \mathrm{C}$ may indicate that this temperature is close to the upper physiological limit for hybrids (Fig. 6). In agreement, swimming speeds $(U)$ of hybrid and $H$. laevigata larvae also decreased at temperatures higher than $25^{\circ} \mathrm{C}$ (higher temperature values not determined for $H$. rubra) (Fig. 3). At $20^{\circ} \mathrm{C}$, $U$ was similar not only between species but also across development, whereas at $25^{\circ} \mathrm{C}, \mathrm{H}$. rubra and hybrids displayed an increase in $U$ with increasing development. The latter is not a simple consequence of increasing body size, because larvae do not feed exogenously and hence do not gain mass during larval development (Table 1). The increasing $U$ across development at $25^{\circ} \mathrm{C}$ may instead be related to the larvae acquiring an enhanced motivation to find suitable surfaces for settlement. Yet, finding settlement habitats at such high temperatures may not be favorable for survival. Indeed, larvae of Haliotis sorenseni (Bartsch, 1940) inhabit waters with temperatures of $14-20^{\circ} \mathrm{C}$; development was most rapid at $20^{\circ} \mathrm{C}$, yet high mortality occurred during juvenile development at that temperature (Leighton et al. 1981, Leighton 1972).

It remains unclear why the increase in $U$ at $25^{\circ} \mathrm{C}$ during the development of Haliotis rubra and hybrids in the present study

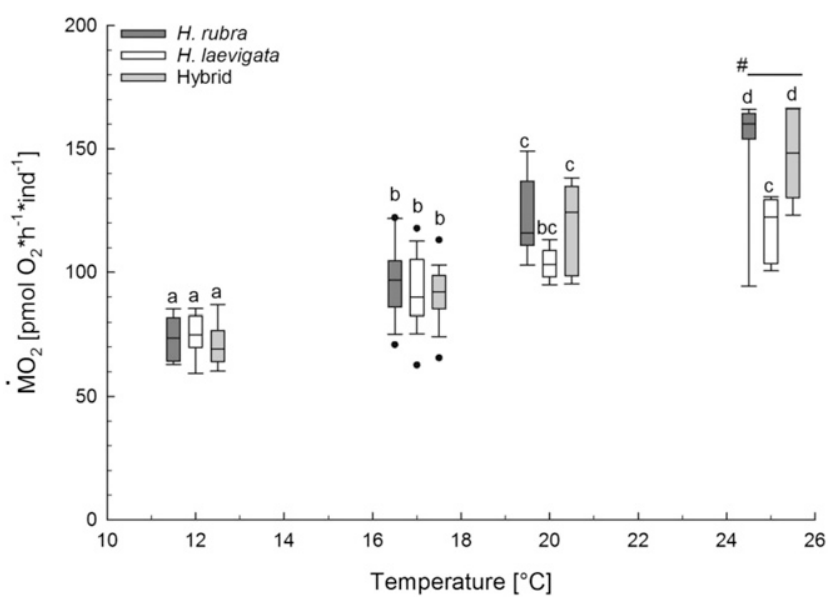

Figure 5. Oxygen consumption rate $\left(\dot{\mathrm{MO}} \mathrm{O}_{2}, \mathrm{pmol} \mathrm{O}_{2} / \mathrm{h} / \mathrm{ind}\right)$ of Haliotis rubra (dark gray bars), Haliotis laevigata (open bars), and hybrids (light gray bars) measured at $12^{\circ} \mathrm{C}, 17^{\circ} \mathrm{C}, 20^{\circ} \mathrm{C}$, and $25^{\circ} \mathrm{C}$, respectively. See Table 1 for veliger developmental day and sample size. The meaning of boxes and whiskers are as described in Fig. 2. Dots symbolize outliers. Different lowercase letters indicate significant differences between temperature treatments for a given group of abalone. \# Indicates significant differences between groups at a given temperature (nonparametric Scheirer-Ray Hare test, $P<0.05$ ).

was not observed for Haliotis laevigata. A potential reason could be associated with energy storages, which become limiting at the end of larval development (Shilling et al. 1996, Moran \& Manahan 2003). It may be that H. laevigata, in comparison with H. rubra and hybrids (hybrids produced via H. rubra ova), has less energy reserves available at the end of larval development and hence is not able to increase $U$ at such high temperatures. In accordance with this hypothesis, a 2-fold difference in lipid reserves between coexisting larvae has been reported for Haliotis sorenseni and the green abalone, Haliotis fulgens (Moran \& Manahan 2003). A study addressing the energy reserves in $H$. rubra, $H$. laevigata, and hybrid abalone larvae could shed light on this idea.

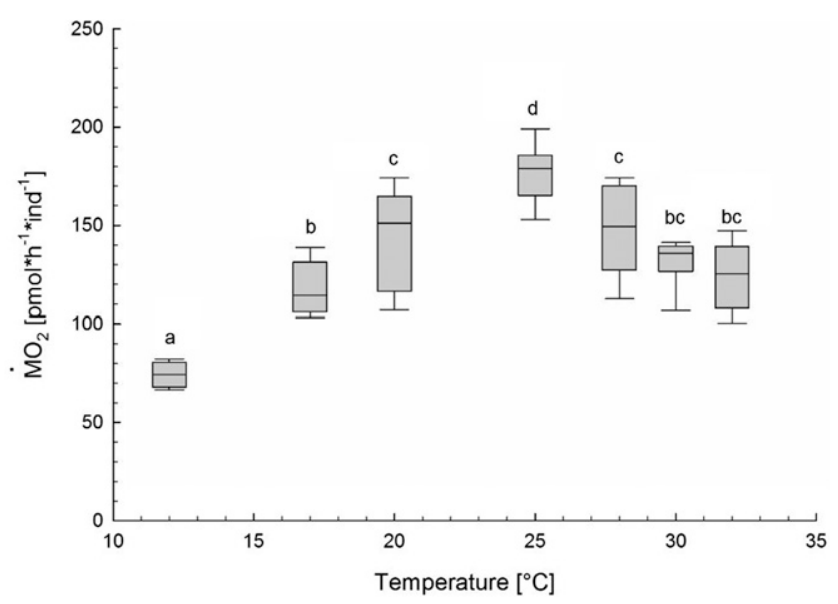

Figure 6. Oxygen consumption rate $\left(\dot{\mathrm{M}} \mathrm{O}_{2}, \mathrm{pmol}_{2} / \mathrm{h} /\right.$ ind $)$ of hybrid larvae from the March population at various temperatures $\left({ }^{\circ} \mathrm{C}\right)$. See Table 1 for veliger developmental days and sample size. The meaning of boxes and whiskers are as described in Fig. 2. Different lowercase letters indicate significant differences between temperatures. 
The $\dot{M O}_{2}$ of veliger larvae decreased with declining temperatures to the lowest tested temperature of $12^{\circ} \mathrm{C}$ (Fig. 5). This suggests that the lower physiological limit is below $12^{\circ} \mathrm{C}$, which is in accordance with previous reports (Grubert \& Ritar 2004). The biological zero point (BZP) is the theoretical threshold below which larval development is stunted and is reported as $7.8^{\circ} \mathrm{C}$ for Haliotis rubra and $7.2^{\circ} \mathrm{C}$ for Haliotis laevigata (Grubert \& Ritar 2004). Grubert and Ritar (2004), however, determined the BZP of larvae originating from wildcaught broodstock from cooler Tasmanian waters, whereas larvae in the present study originated from cultured broodstock and were raised in warmer conditions, which may influence the BZP. In addition, $U$ of $H$. rubra veligers as well as $U$ of $H$. laevigata veligers was similar between $12^{\circ} \mathrm{C}$ and $17^{\circ} \mathrm{C}$ (Fig. 3) and larval swimming behavior was extremely sluggish and circular at $12^{\circ} \mathrm{C}$ in comparison with the more directional swimming behavior at higher temperatures. This suggests that $12^{\circ} \mathrm{C}$ is approaching the lower temperature limit for swimming ability in larvae. Similar observations have been reported for white abalone Haliotis sorenseni larvae which developed but did not settle successfully during temperature exposures of 10 $12^{\circ} \mathrm{C}$ (Leighton 1972). Further, postlarvae of the red abalone Haliotis rufescens (Swainson, 1822), the pink abalone Haliotis corrugata (Wood, 1828), and the green abalone Haliotis fulgens were also able to survive at temperatures of $10-12{ }^{\circ} \mathrm{C}$ but were not able to right themselves when turned over (Leighton 1974). White, red, pink, and green abalone inhabit waters with temperatures of $14-20^{\circ} \mathrm{C}$, which are similar to the temperatures in the Victorian waters where the founder broodstock for larvae from the present study were sourced. It may be possible that the temperatures that resulted in impaired swimming ability in this study and settling success in white abalone as well as righting ability in red, pink, and green abalone are indicative of the lower thermal limit for physiological function and thus constrain distribution within these temperate abalone species.

At $17-25^{\circ} \mathrm{C}$, hybrids from the March population had higher $\dot{\mathrm{MO}} \mathrm{O}_{2}$ in comparison with hybrids (and pure species) from the December population (Figs. 4 and 6). For example, hybrid $\mathrm{MO}_{2}$ at $17^{\circ} \mathrm{C}$ was $91 \mathrm{pmol} / \mathrm{h} /$ ind for the December population and $118 \mathrm{pmol} / \mathrm{h} /$ ind for the March population. Differences in $\mathrm{MO}_{2}$ between larval populations of Haliotis rubra/Haliotis laevigata hybrids from the same farm have been reported previously
(Alter et al. 2016). Oxygen consumption rates $\left(\dot{\mathrm{MO}}_{2}\right)$ varied between 99 and $146 \mathrm{pmol} / \mathrm{h} /$ ind at $16^{\circ} \mathrm{C}$ and it was suggested that the differences may be due to heritable and/or maternal variation (Alter et al. 2016). Indeed, one-third of the variation in veliger $U$ and growth rates was caused by genetic and maternal factors in the common slipper snail, Crepidula fornicata (Linnaeus, 1758) (Hilbish et al. 1999). High levels of genetic variation for veliger growth rates have also been reported for other molluscs, such as the oyster Crassostrea virginica (Gmelin, 1791), the hard clam Mercenaria mercenaria (Linnaeus, 1758), and the Manila clam Ruditapes philippinarum (Adams and Reeve, 1850) (Hilbish et al. 1993, Newkirk et al. 1977 in Hilbish et al. 1999, Yan et al. 2014).

In summary, results of the present study do not support the original hypothesis that $T_{\text {pref }}$ is different between groups of abalone. However, findings of the present study suggest that the current aquaculture industry best practices for rearing pure and hybrid groups of early-stage larvae at $16-18^{\circ} \mathrm{C}$ are appropriate (Heasman \& Savva 2007, L. McPherson, JTA, personal communication, November 2015). The $\mathrm{T}_{\text {pref }}$ of 1- and 2-day-old veligers was between $15.9^{\circ} \mathrm{C}$ and $18.3^{\circ} \mathrm{C}$ (Fig. 2). These temperatures represent the approximate average temperature range of physiologically limiting low and high temperatures of $12^{\circ} \mathrm{C}$ and $25^{\circ} \mathrm{C}$, respectively. Further, $U$ of veligers at $\mathrm{T}_{\text {pref }}\left(\sim 17^{\circ} \mathrm{C}\right)$ was constant during development (Fig. 3). Three-day-old veliger larvae are close to settlement and preferred higher temperatures between $19.5^{\circ} \mathrm{C}$ and $20.2^{\circ} \mathrm{C}$, in comparison with 1 - and 2-day-old veligers. This may indicate that temperatures in the hatchery could be slightly increased during later stage larval development prior to settlement. However, this suggestion should be considered with care until similar studies are completed with settled larvae and early juveniles. Adult $\mathrm{T}_{\text {pref }}$ has been reported as $17^{\circ} \mathrm{C}$ and $19^{\circ} \mathrm{C}$ in Haliotis rubra and Haliotis laevigata, respectively (Gilroy \& Edwards 1998). This may indicate that $\mathrm{T}_{\text {pref }}$ may decrease after metamorphosis in abalone as demonstrated in other aquatic organisms (Dupré \& Petranka 1985, Wollmuth et al. 1987).

\section{ACKNOWLEDGMENTS}

We would like to thank Jade Tiger Abalone for their support and for providing abalone larvae. We are thankful for scholarships and funding provided by Sense-t and CSIRO.

\section{LITERATURE CITED}

Abramoff, M. D., P. J. Magalhaes \& S. J. Ram. 2004. Image processing with ImageJ. Biophoton. Int. 11:36-42.

Alter, K., S. J. Andrewartha \& N. G. Elliott. 2016. Hatchery conditions do not negatively impact respiratory response of early life-stage development in Australian hybrid abalone. J. Shellfish Res. 35:585-591.

Angilletta, M. J. 2009. Thermal adaptation: a theoretical and empirical synthesis. Oxford, United Kingdom: Oxford University Press. $304 \mathrm{pp}$.

Australian Government Bureau of Meteorology. 2016. Australian climate variability and change-time series graphs. Available at: http://www.bom.gov.au/cgi-bin/climate/change/timeseries. cgi.

Babcock, R. \& J. Keesing. 1999. Fertilization biology of the abalone Haliotis laevigata: laboratory and field studies. Can. J. Fish. Aquat. Sci. 56:1668-1678.
Breen, P. A. \& B. E. Adkins. 1980. Spawning in a British Columbia population of northern abalone, Haliotis kamtschatkana. Veliger 23:177-179.

Brown, L. D. 1995. Genetic evidence for hybridisation between Haliotis rubra and H. laevigata. Mar. Biol. 123:89-93.

Casterlin, M. E. \& W. W. Reynolds. 1980. Behavioral response of the New England dog whelk, Nassarius trivittatus, to a temperature gradient. Hydrobiologia 69:79-81.

Chapperon, C. \& L. Seuront. 2011a. Behavioral thermoregulation in a tropical gastropod: links to climate change scenarios. Glob. Change Biol. 17:1740-1749.

Chapperon, C. \& L. Seuront. 2011b. Space-time variability in environmental thermal properties and snail thermoregulatory behaviour. Funct. Ecol. 25:1040-1050.

Crofts, D. R. 1937. The development of Haliotis tuberculata: with special reference to organogenesis during torsion. Philos. Tans. $R$. Soc. Lond. B. Biol. Sci. 288:219-268. 
Dupré, R. K. \& J. W. Petranka. 1985. Ontogeny of temperature selection in larval amphibians. Copeia 462-467.

Floyd, R. B. 1984. Variation in temperature preference with stage of development of Bufo marinus larvae. J. Herpetol. 18:153-158.

Gilroy, A. \& S. J. Edwards. 1998. Optimum temperature for growth of Australian abalone: preferred temperature and critical thermal maximum for blacklip abalone, Haliotis rubra (Leach), and greenlip abalone, Haliotis laevigata (Leach). Aquacult. Res. 29:481-485.

Green, B. S. \& R. Fisher. 2004. Temperature influences swimming speed, growth and larval duration in coral reef fish larvae. J. Exp. Mar. Biol. Ecol. 299:115-132.

Grubert, M. A. \& A. J. Ritar. 2004. The effect of temperature on the embryonic and larval development of blacklip (Haliotis rubra) and greenlip (H. laevigata) abalone. Inv. Rep. Dev. 45:197-203.

Guo, X. M. 2009. Use and exchange of genetic resources in molluscan aquaculture. Rev. Aquacult. 1:251-259.

Hammond, L. M. \& G. E. Hofmann. 2010. Thermal tolerance of Strongylocentrotus purpuratus early life history stages: mortality, stress-induced gene expression and biogeographic patterns. Mar. Biol. 157:2677-2687.

Heasman, M. P. \& N. Savva. 2007. Manual for intensive hatchery production of abalone: theory and practice for year-round, high density seed production of blacklip abalone (Haliotis rubra). Nelson Bay, New South Wales: NSW Department of Primary Industries, Port Stephens Fisheries Centre. 27 pp.

Hecht, T. 1994. Behavioural thermoregulation of the abalone, Haliotis midae, and the implications for intensive culture. Aquaculture 126:171-181.

Hilbish, T. J., E. P. Winn \& P. D. Rawson. 1993. Genetic variation and covariation during larval and juvenile growth in Mercenaria mercenaria. Mar. Biol. 115:97-104.

Hilbish, T. J., K. Sasada, L. S. Eyster \& J. A. Pechenik. 1999. Relationship between rates of swimming and growth in veliger larvae: genetic variance and covariance. J. Exp. Mar. Biol. Ecol. 239:183-193.

Leighton, D. L. 1972. Laboratory observations on the early growth of the abalone, Haliotis sorenseni, and the effect of temperature on larval development and settling success. Fish Bull. 70:373-380.

Leighton, D. L. 1974. The influence of temperature on larval and juvenile growth in three species of southern California abalones. Fish Bull. 72:1137-1145.

Leighton, D. L., M. J. Byhower, J. C. Kelly, G. N. Hooker \& D. E. Morse. 1981. Acceleration of development and growth in young green abalone (Haliotis fulgens) using warmed effluent seawater. J. World. Maricult. Soc. 12:170-180.

Martin, T. L. \& R. B. Huey. 2008. Why "suboptimal" is optimal: Jensen's inequality and ectotherm thermal preferences. Am. Nat. 171:102-118.

McShane, P. E., K. P. Black \& M. G. Smith. 1988. Recruitment processes in Haliotis rubra (Mollusca: Gastropoda) and regional hydrodynamics in southeastern Australia imply localized dispersal of larvae. J. Exp. Mar. Biol. Ecol. 124:175-203.

Moran, A. L. \& D. T. Manahan. 2003. Energy metabolism during larval development of green and white abalone, Haliotis fulgens and $H$. sorenseni. Biol. Bull. 204:270-277.

Muñoz, J. L., G. R. Finke, P. A. Camus \& F. Bozinovic. 2005. Thermoregulatory behavior, heat gain and thermal tolerance in the periwinkle Echinolittorina peruviana in central Chile. Comp. Biochem. Physiol. A 142:92-98.

Myrick, C. A. 2009. A low-cost system for capturing and analyzing the motion of aquatic organisms. J. N. Am. Benthol. Soc. 28:101-109.

Newkirk, G., L. E. Haley, D. L. Waugh \& R. Doyle. 1977. Genetics of larval and spat growth rate in the oyster Crassostrea virginica. Mar. Biol. 41:49-52.

Prince, J. D., T. L. Sellers, W. B. Ford \& S. R. Talbot. 1987. Experimental evidence of limited dispersal of haliotid larvae (genus Haliotis: Mollusca: Gastropoda). J. Exp. Mar. Biol. Ecol. 106:243263.

Reynolds, W. W. \& M. E. Casterlin. 1979. Behavioral thermoregulation and the final preferendum paradigm. Am. Zool. 19:211-224.

Scheirer, J., W. S. Ray \& N. Hare. 1976. The analysis of ranked data derived from completely randomized factorial designs. Biometrics 32:429-434.

Schindelin, J., C. T. Rueden, M. C. Hiner \& K. W. Eliceiri. 2015. The ImageJ ecosystem: an open platform for biomedical image analysis. Mol. Reprod. Dev. 82:518-529.

Shepherd, S. A. 1973. Studies on southern Australian abalone (genus Haliotis). I. Ecology of five sympatric species. Mar. Freshw. Res. 24:217-258.

Shilling, F. M., O. Hoegh-Guldberg \& D. T. Manahan. 1996. Sources of energy for increased metabolic demand during metamorphosis of the abalone Haliotis rufescens (Mollusca). Biol. Bull. 191:402-412.

Sokal, R. R. \& F. J. Rohlf. 1995. Biometry. The principles and practice of statistics in biological research, $3^{\text {rd }}$ edition. New York, NY: W. H. Freeman. 776 pp.

Videler, J. J. 1993. Fish swimming, vol. 10. London, United Kingdom: Chapman and Hall. 260 pp.

Wiggins, P. R. \& P. B. Frappell. 2000. The influence of haemoglobin on behavioural thermoregulation and oxygen consumption in Daphnia carinata. Physiol. Biochem. Zool. 73:153-160.

Wollmuth, L. P., L. I. Crawshaw, R. B. Forbes \& D. A. Grahn. 1987. Temperature selection during development in a montane anuran species, Rana cascadae. Physiol. Zool. 60:472-480.

Yan, X., Z. Huo, F. Yang \& G. Zhang. 2014. Heritability of larval and juvenile growth for two stocks of Manila clam Ruditapes philippinarum. Aquacult. Res. 45:484-490.

Zippay, M. L. \& G. E. Hofmann. 2010. Physiological tolerances across latitudes: thermal sensitivity of larval marine snails (Nucella spp.). Mar. Biol. 157:707-714. 